\title{
IMPLEMENTASI PENYELENGGARAAN ISO 9001:2008 DALAM BIDANG MUTU LAYANAN ADMINISTRASI AKADEMIK
}

\author{
Triyanto, Lantip Diat Prasojo \\ FIP Universitas Negeri Yogyakarta, Pascasarjana Universitas Negeri Yogyakarta \\ tri_fipuny@yahoo.com lantip1975@gmail.com
}

\begin{abstract}
Abstrak
Penelitian ini bertujuan untuk mengetahui: (1) persepsi karyawan subag pendidikan atau subag akademik terhadap implementasi ISO 9001:2008 di UNY dan (2) faktor penghambat dan usaha-usaha yang dilakukan dalam implementasi ISO 9001:2008 bidang mutu layanan administrasi akademik di UNY. Penelitian ini menggunakan pendekatan kuantitatif dengan metode deskriptif. Penelitian dilakukan pada bulan Oktober sampai dengan Desember 2012 di UNY. Sampel sejumlah 96 karyawan ditentukan menggunakan teknik Proportional Stratified Random Sampling. Sampel mahasiswa berjumlah 105 ditentukan dengan teknik simple random sampling. Data dikumpulkan melalui angket dan dianalisis dengan teknik deskriptif kuantitatif dan kualitatif. Hasil penelitian menunjukkan bahwa secara keseluruhan skor persepsi karyawan subag pendidikan dalam implementasi delapan prinsip ISO tersebut di tingkat UNY adalah 17.438 atau 78,98\% dan termasuk kategori baik, sedangkan skor persepsi mahasiswa 11.104 atau $68,23 \%$ serta berkategori baik. Faktor penghambat terletak pada kebijakan pimpinan fakultas, ketersediaan dana, SDM, keterbatasan sarana dan prasarana, SIM dan SOP layanan administrasi. Solusi yang dilakukan adalah mempererat koordinasi dan komunikasi dengan pimpinan, perawatan rutin sarana dan prasarana dan berpedoman pada buku panduan dan peraturan yang ada.
\end{abstract}

Kata kunci: persepsi karyawan, ISO 9001:2008, hambatan dan solusi

\section{THE IMPLEMENTATION OF THE INTERNATIONAL ORGANIZATION FOR STANDARDIZATION (ISO) 9001:2008 IN THE FIELD OF ACADEMIC ADMINISTRATION SERVICE QUALITY}

\begin{abstract}
This study aims to reveal: (1) the perceptions of the employees in the sub-section of education or the sub-section of academic affairs on the implementation of ISO 9001: 2008 at YSU) and (2) the inhibiting factors and the attempts made in the implementation of the organization of ISO 9001:2008 in the field of academic administration service quality at YSU. This study employed the quantitative approach using the descriptive method. It was conducted from October to December 2012 at YSU. A sample of 95 employees was established using the proportional stratified random sampling technique, and a sample of 105 students was established using the simple random sampling technique. The data were collected by means of a questionnaire and analyzed using the quantitative and qualitative descriptive techniques. The results of the study show that on the whole, the score of the perceptions of the employees of the subsection of education in the implementation of the eight ISO principles at YSU is 17.438 or $78.98 \%$, and in the good category, while the score of the perceptions of students is 11.104 or $68.23 \%$, and in the good category. The inhibiting factors include the leaders' policies, the fund availability, the human resources, the limited infrastructure facilities, the information system management, and the standard operation procedure for administration services. The solutions made include the improvement of coordination and communication with the leaders, the maintenance of infrastructure facilities, and the conformity to the available guidebook and regulations.
\end{abstract}

Keywords: employees' perceptions, ISO 9001: 2008, obstruction and solution 


\section{Pendahuluan}

Pendidikan di Indonesia bertujuan meningkatkan kualitas sumber daya manusia Indonesia. Dalam melaksanakan pendidikan tersebut salah satu cara yaitu berorientasi pada mutu pendidikan. Dengan ini diharapkan menghasilkan output dan out come yang mampu sesuai dengan keinginan dari masyarakat. Namun masalah mutu pendidikan tampaknya belum juga dapat terselesaikan dengan baik. Masalah mutu pendidikan di Indonesia memang sangat komplek dan rumit, hal ini ditandai dengan fenomena antara lain rendahnya mutu lulusan, penyelesaian masalah pendidikan yang tidak tuntas (Syafaruddin, 2002, p.19). Masalah mutu pendidikan harus menjadi perhatian serius pemerintah. Dalam pengimplementasiannya upaya peningkatan mutu pendidikan menjadi tanggung jawab bersama, dan bukan hanya pemerintah. Harapannya yaitu mutu pendidikan bagus, maka bagus pula kualitas peradaban bangsa tersebut.

Mutu pendidikan merupakan salah satu tolok ukur keberhasilan sebuah proses pendidikan yang bisa dirasakan oleh masyarakat mulai dari input (masukan), proses pendidikan yang terjadi, hingga output (produk keluaran) dari sebuah proses pendidikan. Mutu pendidikan dapat diartikan sebagai kemampuan organisasi pendidikan dalam pengelolaan secara operasional terhadap komponen-komponen yang berkaitan dengan sekolah, sehingga menghasilkan nilai tambah terhadap komponen tersebut menurut norma/standar yang berlaku.

Pembangunan pendidikan perlu diimbangi dengan peningkatan mutu pendidikan. Menurut Sallis (2010, p.45), "Peningkatan mutu dalam pendidikan harus dilaksanakan secara terus-menerus". Peningkatan mutu menjadi semakin penting bagi institusi karena digunakan untuk memperoleh kontrol yang lebih baik melalui usahanya sendiri. Institusi-institusi pendidikan harus mampu memberikan pendidikan yang bermutu dan berlayanan baik pada peserta didiknya. Hal ini dikarenakan tingkat persaingan antarinstitusi pendidikan semakin ketat. Semuanya menjadi tanggung jawab bersama terhadap pelaksanaan pendidikan di berbagai bidang dan tingkatan, termasuk di dalamnya pendidikan tingkat tinggi atau perguruan tinggi. Perguruan tinggi harus mampu meningkatkan mutu dengan tujuan untuk menghasilkan output yang mampu memenuhi standar yang telah ditetapkan. Perguruan tinggi dituntut untuk mampu menghasilkan lulusan yang mampu memenuhi dunia kerja dan usaha, serta bersaing dengan lulusan lainnya. Ditambah lagi dengan masuknya berbagai perguruan tinggi asing ke Indonesia menambah tingkat persaingan antarperguruan tinggi, karena menawarkan mutu dan layanan yang terbaik juga.

Sallis (2010, p.32) mengatakan "Institusi-institusi pendidikan perlu mengembangkan sistem-sistem mutu, agar dapat membuktikan kepada public bahwa institusi-institusi tersebut dapat memberikan layanan pendidikan yang bermutu dan berkuliatas". Peningkatan kompetisi antarinstitusi perguruan tinggi dalam memberikan mutu dan layanan semakin ke depan sangat ketat. Beberapa perguruan tinggi mengadakan berbagai macam program dalam hal mutu layanan yang menarik bagi mahasiswa. Mulai dari pemberian kemudahan belajar, kemudahan biaya kuliah hingga percepatan studi. Berbagai macam perguruan tinggi tersebut yang pada ujungnya ingin menjaring animo mahasiswa. Perguruan tinggi terkadang belum menyentuh pada subtansi peningkatan yang sebenarnya yaitu peningkatan mutu layanan pendidikan untuk menghasilkan lulusan dengan kompetensi sesuai dengan harapan dunia kerja.

"Sistem layanan administrasi yang ada sekarang belum bekerja dengan baik. Kita banyak temukan perencanaan itu baru disusun ketika akan ada proses assessment akreditasi dari BAN," kata Illa Sailah (2011). Ini menunjukkan bahwa sistem kendali dokumentasi dan kebijakan-kebijakan yang diputuskan oleh pimpinan belum tentu dilaksanakan secara benar oleh bawahannya. Hal tersebut bisa disebabkan karena kurangnya koordinasi dan komunikasi 
antarjenjang organisasi di perguruan tinggi atau antarinstitusi di luar perguruan tinggi. Selain itu bisa pula disebabkan karena sistem birokrasi dalam pengurusan administrasi yang panjang dan rumit. Semua ini tentu akan sangat mengurangi kepuasan pelanggan terutama mahasiswa dalam menerima layanannya. Pendidikan yang diharapkan adalah pendidikan yang bermutu atau berkualitas sesuai harapan pelanggan. Padahal seharusnya praktek yang baik dalam sistem layanan akademik adalah proses penilaian praktek baik PT dinilai dari kesesuaian perencanaan dan pelaksanaan dengan adanya dokumen mutu, manual mutu, kebijakan mutu, SOP mutu dan formulir mutu, baik dilakukan di tingkat universitas, fakultas hingga program studi.

Dalam peningkatan mutu tersebut, salah satu usahanya dengan penerapan manajemen mutu terpadu (TQM). "TQM sebagai sebuah sistem, tidak hanya mengurangi masalah pendidikan, tapi juga sebagai model yang mengutamakan perbaikan secara berkelanjutan" (Syafaruddin, 2002, p.21). Masalah sistem layanan akademik juga termasuk dalam masalah pendidikan dan bisa diselesaikan dengan model TQM. Dalam penerapannya, sistem yang harus dibangun layanan akademik mengutamakan pencapaian harapan pelanggannya melalui upaya perbaikan secara terusmenerus. Model perbaikan bisa dari dalam institusi perguruan tinggi itu sendiri atau dengan mengundang pihak luar perguruan tinggi untuk mengontrol dan mengevaluasi dari kinerjanya, sehingga hasilnya akan lebih terpercaya. Peningkatan mutu layanan akademik juga memerlukan berbagai pengaturan dan standarisasi yang digunakan sebagai pengontrol dan pengatur dalam pencapaian tujuannya Salah satu usaha yang dilakukan adalah dengan penerapan ISO atau penyelenggaraan International Organization For Standardization. Standar ini digunakan sebagai skala internasional.

ISO sendiri terdiri berbagai macam dan salah satunya adalah ISO 9001: 2008. Kepuasan pelanggan dan perbaikan yang terus-menerus merupakan sasaran utama dari ISO 9001: 2008. Pengendalian dan pengontrolan terhadap berbagai usaha serta dokumentasi sangat menentukan sekali dalam pelaksanaan ISO. Begitu pula sistem layanan akademik di perguruan tinggi, dengan penerapan ISO diharapkan tercapai tujuan yaitu terlayaninya sesuai prosedur yang cepat, tepat dan memuaskan. Sistem yang terbangun setelah ISO adalah tidak rumit, mudah diakses dan mudah pelayanannya, tanpa mengurangi mutu yang telah ditetapkan.

Universitas Negeri Yogyakarta merupakan salah satu institusi perguruan tinggi yang sedang menuju World Class University. Pengakuan internasional berupa sertifikasi terhadap kegiatan manajemen, proses dan fasilitas pendukung sangat diperlukan dalam persaingan internasional. Berbagai kebijakan dan peraturan dilakukan untuk mencapai tujuan tersebut. Semuanya dilakukan untuk memuaskan pelanggan dari UNY, salah satunya yaitu SMM ISO 9001: 2008.

Universitas Negeri Yogyakarta mengadopsi, merancang, menerapkan, memelihara dan menyempurnakan secara terus-menerus SMM (Standar Mutu Manajemen) yang mengacu pada persyaratan standar ISO 9001: 2008. Semua persyaratan dalam SMM ISO 9001: 2008 diaplikasikan sesuai ruang lingkup yang ditetapkan. Tujuan pengadopsian SMM ini dalam upaya untuk menyelenggarakan pendidikan dan pengajaran yang berkualitas. Namun saat ini ada beberapa fakultas dan bidang baru yaitu BAKI kecuali FT dan Pascasarjana, yang telah habis masanya dan belum diperpanjang lagi. Hal ini mengurangi semangat dalam pelaksanaan ISO tersebut secara keseluruhan.

Karyawan layanan administrasi akademik yang merupakan pelaku utama dari pelaksanaan pelayanan akademik, tentu memiliki persepsi/pandangan yang berbeda-beda terhadap pelaksanaan atau penerapan ISO 9001: 2008 dalam menjamin mutu dan layanan. Sementara mahasiswa merupakan pelanggan utama dari subag pendidikan juga mempunyai persepsi berbeda terhadap layanan yang diterimanya. 
Pengukuran persepsi ini berguna untuk mengetahui apa yang seharusnya berjalan dengan baik, tapi masih menimbulkan berbagai permasalahan juga dalam pelaksanaannya. Dengan mengetahui persepsinya, dapat digunakan untuk mengetahui implementasi ISO tersebut dan dijadikan dasar untuk membuat kebijakan baru dalam meningkatkan mutu dan layanannya.

Goldstrein (2010, p.8) mengatakan

"Perception is conscious sensory experience. These two additional steps-recognition and action-are behaviors that are important outcomes of the perceptual process". Sementara menurut Schunk (2009, p.141) mengatakan "Perception (patter recognition) refers to attaching meaning to environmental inputs received through the sense". Intinya persepsi adalah pengalaman sadar atau nyata dari indrawi dan mengacu dari lingkungan. Di sini ada dua langkah tambahan yaitu penerimaan dan tindakan.

Menurut Husd, Barcelona dan Meldrum (2008, p.55), "Effectiveness is capability of an organization to achieve its goals and objecttives" (keefektifan adalah kemampuan organisasi dalam mencapai tujuan dan objeknya). Dalam hal ini efektifitas dapat dinyatakan sebagai tingkat keberhasilan dalam mencapai tujuan atau sasarannya.

International Organization For Standardization (ISO) adalah badan standar dunia yang dibentuk untuk meningkatkan perdagangan internasional yang berkaitan dengan perubahan barang dan jasa yang dibentuk tahun 1947. International Organization For Standardization (ISO) adalah sebuah kata yang berasal dari bahasa Yunani yang berarti "sama" (Rudi Suardi, 2003, p.21). Salah satu kunci sukses agar dapat bersaing di pasar global adalah kemampuan untuk memenuhi atau melampaui standar-standar internasional yang berla$\mathrm{ku}$. Saat ini jumlah negara yang menjadi anggota ISO adalah 246 negara di seluruh dunia serta berkedudukan di Jenewa, Swiss. Tujuan ISO adalah mengembangkan dan mempromosikan standar untuk umum yang berlaku secara internasional (Muhammad Nur Nasution, 2003, p.218).
International Organization For Standardization (ISO) merupakan model dalam peningkatan mutu (Husaini Usman, 2011, p.520). Mutu adalah sebuah proses terstruktur untuk memperbaiki keluaran yang dihasilkan. Sejarah salah satu penyebab terpenting munculnya mutu berasal dari bangkitnya Jepang sebagai negara adidaya ekonomi. Meningkatnya persaingan semakin menyadarkan perusahaan akan mutu sehingga persaingan dalam mutu meningkat drastis. Mutu adalah sesuatu yang dapat disempurnakan (Rudi Suardi, 2003, p.1).

Menurut Husaini Usman (2011, p.513), "Mutu ialah produk dan atau jasa yang sesuai dengan standar mutu yang telah ditetapkan dan memuaskan pelanggan". Sementara menurut Sallis (2010, p.56), mutu adalah "Sesuatu yang memuaskan dan melampaui keinginan dan kebutuhan pelanggan". Berdasarkan pendapat tadi maka mutu merupakan sesuatu produk dan atau jasa yang sesuai dengan standar mutu yang telah ditetapkan dan memuaskan dan melampui kebutuhan dan keinginan pelanggan.

Menurut ST Microelectronics (2010) "ISO 9001 certification is an important measure of management and operational controls, as it evaluates organizations according to the same rigorous standards employed by the most highly respected manufacturing companies in the world".

Pendapat lainnya menurut ISO Central, Secretariat (2010) menyatakan:

Through the network and collaboration of its national member bodies, international liaisons, regional cooperation and partner organizations, ISO constitutes a leading platform for the production of globally and market relevant international Standards. ISO's consensus-building mechanism, multi-sector coverage and ability to efficiently disseminate and promote its range of deliverables are recognized and relied upon by industry, public authorities, consumers and other stakeholders. Thus helping to materialize the assessment procedure accepted everywhere in this way, ISO contributes to a more efficient and sustainable world economy. 
Titik beratnya dari hal di atas yaitu melalui jaringan dan kolaborasi dari badan nasional anggota, penghubung internasional, kerja sama regional dan organisasi mitra, ISO merupakan platform terkemuka untuk produksi global dan standar pasar internasional yang relevan. ISO membangun konsensus mekanisme, multisektor cakupan, kemampuan untuk secara efisien menyebarluaskan dan mempromosikan jangkauan kiriman diakui serta diandalkan oleh industri, otoritas publik, konsumen dan stakeholder lainnya. Sehingga membantu untuk mewujudkan prosedur penilaian diterima di setiap tempat dengan cara ini, ISO memberikan kontribusi pada ekonomi dunia yang lebih efisien dan berkelanjutan.

Delapan prinsip manajemen kualitas yang menjadi landasan ISO 9001: 2008, yaitu:

- Fokus Pelanggan: pelanggan adalah "Sosok dengan siapa berinteraksi langsung atau tidak dalam pengadaan barang dan pelayanan (jasa)" (Agus Syukur, 2010, p.45). Kehidupan institusi tergantung pada pelanggannya. Kepuasan pelanggan merupakan satu keadaan yang mana kebutuhan, keinginan, dan harapan pelanggan dapat terpenuhi. Faktorfaktor yang mempengaruhi persepsi dan harapan pelanggan adalah kebutuhan dan keinginan, pengalaman masa lalu, pengalaman teman sejawat, dan komunikasi melalui media.

- Kepemimpinan: Menurut Ball (2007, p.449) yaitu "Leadership is a key issue for universities and is increasingly regarded a beneficial to improve performance across all activities, including research" yang artinya kepemimpinan merupakan isu utama bagi universitas dan semakin dianggap sebuah bermanfaat untuk meningkatkan kinerja di semua kegiatan, termasuk penelitian. Para pemimpin organisasi harus menyadari, keberhasilan organisasi tergantung pada seberapa jauh komitmen manajemen menciptakan lingkungan kerja yang kondusif bagi perbaikan kerja para staf dan semangat dan moral kerja karyawan tergantung pada kemampuan memotivasi dari para sege- nap manajemen (Murdifin Haming \& Mahfud Nurnajamuddin, 2007, p.154).

- Pelibatan karyawan: Orang-orang yang berada pada semua tingkat perlu dilibatkan dalam memenuhi kebutuhan pelanggan. Komunikasi antarpihak harus berjalan lancar, dituliskan, dan proses pekerjaan harus dikerjakan sesuai dengan prosedur yang ditetapkan. Keterlibatan karyawan ini dilakukan dengan cara memampukan dan memberikan kesempatan kepada personal untuk merencanakan, menerapkan, serta mengendalikan rencana pekerjaan yang menjadi tanggung jawabnya atau kelompoknya. (Rudi Suardi, 2003, p.51).

- Pendekatan proses: Menurut Rudi Suardi, (2003, p.52) menyatakan standar ISO mengembangkan pemakaian pendekatan proses (process approach) pada masa pembuatan, penerapan, dan peningkatan sistem manajemen mutu yang efektif dengan tujuan meningkatkan kepuasan pelanggan dengan memenuhi berbagai persyaratan pelanggan.

- Pendekatan sistem pada manajemen: "Pendekatan sistem ke manajemen didefinisikan sebagai pengidentifikasian, pemahaman, dan pengelolaan sistem dari proses yang saling terkait untuk pencapaian dan peningkatan sasaran dengan efektif dan efisien" (Rudi Suardi, 2003, p.56). Organisasi harus merencanakan cara memenuhi persyaratan pelanggan. Rencana tersebut meliputi semua aktivitas yang berkaitan dengan mutu dari hubungan awal pelanggan hingga informasi dimanfaatkan oleh pelanggan dan monitoring kepuasaanya.

- Perbaikan berkesinambungan: pada proses ini terjadi proses pendekatan yang terus menerus dan dilakukan dengan segera setelah penyempurnaan. "Peningkatan yang baru dilakukan, direvisi, dan diganti untuk mencapai nilai baru dan lebih baik" (Rudi Suardi, 2003, p.57).

- Pendekatan fakta: keputusan yang efektif adalah keputusan yang berdasarkan analisis data dan informasi yang dapat dipertanggungjawabkan. Berkaitan dengan membuat keputusan tersebut, 
organisasi harus mampu membangun paradigma dalam diri karyawannya. Setiap keputusan yang efektif harus berdasarkan analisis data dan informasi yang akurat, untuk itu sistem informasi harus dibangun baik agar komunikasi berjalan lancar. (Rudi Suardi, 2003, p.58).

- Hubungan pemasok yang saling menguntungkan; "Organisasi dan pemasoknya adalah saling menguntungkan dalam rangka meningkatkan kemampuan keduanya dalam memberikan nilai" (Rudi Suardi, 2003, p.58). Organisasi harus mampu membangun lingkungan yang saling menguntungkan antara organisasi dan pemasok/outsourcesing.

Mutu adalah sebuah proses terstruktur untuk memperbaiki keluaran yang dihasilkan. Menurut Sudarwan Danim (2007, p.53), "Mutu mengandung makna derajat keunggulan suatu produk atau hasil kerja, baik berupa barang maupun jasa". Barang dan jasa pendidikan itu bermakna dapat dilihat dan tidak dapat dilihat, tetapi dapat dirasakan. Dalam konteks pendidikan, pengertian mutu mengacu pada masukan, proses, keluaran, dan dampaknya. Sementara itu pelayanan menurut Ratminto \& Atik Septi Winasih (2008, p.2), tidak kasat mata (tidak dapat diraba) dan melibatkan upaya manusia (karyawan atau peralatan lain yang disediakan oleh perusahaan penyelenggara pelayanan).

Administrasi akademik bertujuan untuk menciptakan mekanisme layanan administrasi akademik yang tertib, efisien dan efektif, sehingga terbina kesatuan pemahaman dan tindakan serta disiplin di kalangan mahasiswa, staf administrasi dan staf pengajar.

Menurut penelitian Sofyan Riyanto (2010) dengan judul Peran Sertifikasi Sistem Manajemen Kualitas ISO 9001: 2008 terhadap Kepuasan Pengguna di Perpustakaan Universitas Sanata Dharma Tahun 2010 yang hasilnya terdapat peran positif yang signifikan $(\mathrm{p}<0,05)$ layanan perpustakaan berdasarkan Sistem Manajemen Kualitas ISO 9001: 2008 (yang meliputi atribut: keberwujudan, keandalan, daya tanggap, keterjaminan, dan empati) memberi kepuasan pemustaka di Perpustakaan Universitas Sanata Dharma Yogyakarta.

Sehubungan dengan pertimbangan luasnya cakupan kerja dan bidang kerja yang telah mendapatkan sertifikasi ISO 9001: 2008, penelitian ini dibatasi hanya pada persepsi karyawan Bagian Layanan Administrasi Akademik dengan diwakili karyawan Subag Pendidikan dan Subag Akademik yang melayani administrasi akademik dan yang dilayani Administrasi Akademik yaitu persepsi mahasiswa UNY. Penelitian ini difokuskan pada implementtasi penyelenggaraan ISO 9001: 2008 dalam bidang mutu layanan administrasi akademik di UNY terutama implementasi delapan prinsip ISO 9001: 2008. Di samping itu juga dipusatkan pada hambatan dan solusi yang dilaksanakan oleh karyawan Subag Pendidikan dan Subag Akademik di Universitas Negeri Yogyakarta.

Kegunaan penelitian ini secara teoretik bagi Jurusan Manajemen Pendidikan yaitu menambah informasi dan pengetahuan yang berarti bagi kemajuan di bidang manajemen pendidikan terutama pada Manajemen Mutu Terpadu tentang implementasi penyelenggaran ISO 9001:2008. Sementara secara praktik, kegunaan penelitian ini adalah sebagai informasi pelaksanaan ISO 9001:2008 dalam bidang kualitas mutu dan layanan bagi karyawan Subag Pendidikan dan pascasarjana khususnya dan karyawan UNY. Selain itu juga sebagai bahan informasi bagi pimpinan fakultas atau universitas di Universitas Negeri Yogyakarta dalam meningkatkan kualitas mutu dan pelayanan proses layanan administrasi akademik yang sesuai ISO 9001: 2008.

Definisi operasional penelitian ini adalah Implementasi penyelenggaran ISO 9001:2008 dilaksanakan oleh Subag Pendidikan dan Subag Akademik yang bertugas melayani Administrasi Akademik dari mahasiswa. Dalam upaya mengetahui keterlaksanaannya, maka diperlukan evaluasi yang salah satunya melalui persepsi dari karyawannya dan mahasiswa. Persepsi karyawan bagian layanan administrasi akademik terhadap implementasi penye- 
lenggaraan, ISO 9001: 2008 adalah tanggapan atau pendapat karyawan Subag Pendidikan dan Subag Akademik yang bertugas memberikan layanan administrasi akademik. Kemudian persepsi mahasiswa tentang sampai seberapa besar pencapaian dalam penyelenggaraan ISO 9001: 2008 melalui penerapan dari penyelenggaraan ISO 9001: 2008 adalah tanggapan atau pendapat mahasiswa UNY yang mendapatkan pelayanan adminitrasi akademik yang diberikan oleh Subag Pendidikan dan Subag Akademik.

\section{Metode Penelitian}

Jenis Penelitian

Dalam penelitian ini menggunakan pendekatan kuantitatif. Instrumen yang digunakan dalam penelitian ini adalah standar yang terdapat dalam delapan prinsip ISO 9001: 2008. Penelitian ini merupakan jenis penelitian deskriptif dengan menggunakan pendekatan kuantitatif. Penelitian tentang persepsi ini menggunakan data kuantitatif melalui angket dengan melibatkan karyawan yang menangani layanan administrasi akademik yaitu Subag Pendidikan dan Subag Akademik di Universitas Negeri Yogyakarta. Angket juga diberikan kepada mahasiswa yang merupakan pelanggan dari layanan administrasi akademik, sebagai data pendukung dari data karyawan tersebut.

\section{Waktu dan Tempat Penelitian}

Tempat berlangsung kegiatan penelitian ini di Subag Pendidikan dan Subag Akademik yang telah mendapatkan sertifikat ISO 9001: 2008. Waktu Pelaksanaan penelitian dilaksanakan pada bulan Oktober 2012 sampai dengan bulan Desember 2012.

\section{Target/Subjek Penelitian}

Populasi yang akan diambil dalam penelitian ini adalah Subag Pendidikan dan Subag Akademik yang menurut Subag Kepegawaian UNY pada bulan November
2012 karyawan Subag Pendidikan dan Subag Akademik yaitu 165 orang dengan sampel 95 pegawai. Dalam penelitian ini jumlah sampel mahasiswa 105 diambil secara acak dengan pedoman 15 mahasiswa setiap fakultas dan pascasarjana digunakan untuk penelitian. Teknik pengambilan sampel yang digunakan untuk karyawan proposional random sampling dan mahasiswa adalah simple random sampling.

Objek dalam penelitian ini adalah persepsi Subag Pendidikan dan Subag Akademik, serta persepsi dari mahasiswa UNY tentang Implementasi penyelenggaraan International Organization For Standardization, (ISO) 9001: 2008 dalam bidang mutu layanan akademik di Universitas Negeri Yogyakarta. Dalam penelitian ini, subvariabelnya adalah delapan prinsip manajemen mutu ISO 9001: 2008, yaitu fokus pelanggan, kepemimpinan, pelibatan karyawan, pendekatan proses, pendekatan sistem pada manajemen, perbaikan berkesinambungan, pendekatan fakta dan hubungan pemasok yang saling menguntungkan dalam ISO 9001: 2008 pada layanan administrasi akademik di UNY.

Teknik pengumpulan data yang digunakan adalah angket atau kuesioner. Angket dalam penelitian ini merupakan angket tertutup. Angket yang digunakan adalah angket jenis skala Likert. Bentuk jawaban angket adalah Sangat Baik, Baik, Cukup, Kurang, Sangat Kurang. Angket ini ditujukan kepada karyawan Subag Pendidikan dan Subag Akademik dan mahasiswa di UNY. Sementara angket terbuka hanya digunakan untuk mengetahui hambatan dan solusi yang dilaksanakan karyawan Subag Pendidikan dan Subag Akademik di UNY.

Penelitian ini validitas instrumen yang digunakan adalah validitas isi (content). Dalam menguji validitas isi tersebut menggunakan validitas logis yaitu mengkonsultasikan butir-butir instrumen kepada ahli (experts judgment) dan validitas empiris dengan cara mengujicobakan instrumen kepada 30 karyawan Subag Pendidikan FIP UNY. Pengujian validitas empiris dilakukan dengan rumus korelasi 
product moment dengan angka kasar. Sementara untuk menguji reliabilitas instrumen variabel pada penelitian ini digunakan rumus alpha cronbach.

Teknik Analisis Data

Data yang diperoleh dengan metode angket yang diberikan pada subjek kemudian dianalisis dengan teknik analisis deskriptif. Angket yang digunakan dalam penelitian ini yang terdiri 46 item pertanyaan untuk persepsi karyawan dan 31 item pertanyaan untuk persepsi mahasiswa. Sementara data kualitatif yang berupa peryataan "Sangat Baik", "Baik", "Cukup", "Kurang", "Sangat Kurang" diubah jadi data kuantitatif menjadi 5 interval adalah

Tabel 1. Konversi Jawaban ke Data Kuantitatif

\begin{tabular}{ccc}
\hline Alternatif & \multicolumn{2}{c}{ Skor } \\
\cline { 2 - 3 } Jawaban & Favorable & Unfavorable \\
\hline Sangat Baik & 5 & 1 \\
Baik & 4 & 2 \\
Cukup & 3 & 3 \\
Kurang baik & 2 & 4 \\
Tidak Baik & 1 & 5 \\
\hline
\end{tabular}

Kemudian data dibuat persentase dengan cara yang digunakan yaitu:

$\%=\frac{F}{N} \times 100$

$\mathrm{F}=$ jumlah perolehan skor sebenarnya

$\mathrm{N}=$ Jumlah perolehan skor maksimalnya

Tabel 2. Konversi Data Kuantitatif ke Data Kualitatif dengan Skala Lima

\begin{tabular}{ccc}
\hline $\begin{array}{c}\text { Data } \\
\text { Kuanti- } \\
\text { tatif }\end{array}$ & \multicolumn{1}{c}{ Interval Skor } & $\begin{array}{c}\text { Data } \\
\text { Kuali- } \\
\text { tatif }\end{array}$ \\
\hline 5 & $\mathrm{X}>\overline{\mathrm{X}}_{i}+1,80 \mathrm{SB}_{i}$ & $\begin{array}{c}\text { Sangat } \\
\text { Baik }\end{array}$ \\
4 & $\overline{\mathrm{X}}_{i}+0,60 \mathrm{SB}_{i}<\mathrm{X} \leq \overline{\mathrm{X}}_{i}+1,80 \mathrm{SB}_{i}$ & Baik \\
3 & $\overline{\mathrm{X}}_{i}-0,60 \mathrm{SB}_{i}<\mathrm{X} \leq \overline{\mathrm{X}}_{i}+0,60 \mathrm{SB}_{i}$ & Cukup \\
2 & $\overline{\mathrm{X}}_{i}-1,80 \mathrm{SB}_{i}<\mathrm{X} \leq \overline{\mathrm{X}}_{i}-0,60 \mathrm{SB}_{i}$ & $\begin{array}{c}\text { Kurang } \\
1\end{array}$ \\
$\mathrm{X} \leq \overline{\mathrm{X}}_{i}-1,80 \mathrm{SB}_{i}$ & Sangat \\
& & Kurang \\
\hline
\end{tabular}

Dengan mengetahui persentasenya dapat diketahui peringkat dan berapa persentase kekurangannya. Skor yang diper- oleh kemudian dikonversikan menjadi data kualitatif skala lima.

Sementara untuk data angket terbuka, teknik analisisnya dilakukan dengan display data, mereduksi data kemudian menarik kesimpulan data.

\section{Hasil Penelitian dan Pembahasan}

Dalam penelitian ini menggunakan angket tertutup dengan memakai skala likert sebagai instrumennya. Angket tersebut diberikan kepada karyawan dari Subag Pendidikan dan Subag Akademik di UNY dan mahasiswa UNY. Angket tersebut memberikan keterangan tentang pelaksanaan dari delapan prinsip yang terdapat dalam sistem manajemen mutu ISO 9001: 2008.

Tabel 3. Implementasi 8 Prinsip ISO 9001: 2008 (Menurut Persepsi Karyawan Subag Akademik)

\begin{tabular}{|c|c|c|c|c|}
\hline No & Prinsip & $\begin{array}{l}\text { Jumlah } \\
\text { Skor }\end{array}$ & $\%$ & $\begin{array}{l}\text { Kate- } \\
\text { gori }\end{array}$ \\
\hline 1 & Fokus Pelanggan & 4.237 & 80,3 & Baik \\
\hline 2 & Kepemimpinan & 4.509 & 78,3 & Baik \\
\hline 3 & Pelibatan Karyawan & 1.915 & 79,8 & Baik \\
\hline 4 & Pendekatan Proses & 1.136 & 78,9 & Baik \\
\hline 5 & Pendekatan Sistem & 1.062 & 73,8 & Baik \\
\hline 6 & $\begin{array}{l}\text { Perbaikan } \\
\text { Berkesinambungan }\end{array}$ & 1.910 & 79,6 & Baik \\
\hline 7 & Pendekatan Fakta & 1.865 & 77,7 & Baik \\
\hline 8 & $\begin{array}{l}\text { Hubungan Pemasok } \\
\text { saling Menguntungkan }\end{array}$ & 804 & 83,6 & Baik \\
\hline 9 & UNY & 17.438 & 78.9 & Baik \\
\hline
\end{tabular}

Tabel 4. Implementasi 8 Prinsip ISO 9001: 2008 (Menurut Persepsi Mahasiswa UNY)

\begin{tabular}{|c|c|c|c|c|}
\hline No & Prinsip & $\begin{array}{c}\text { Jumlah } \\
\text { Skor }\end{array}$ & $\%$ & $\begin{array}{l}\text { Kate- } \\
\text { gori }\end{array}$ \\
\hline 1 & Fokus Pelanggan & 3.557 & 67,7 & Cukup \\
\hline 2 & Kepemimpinan & 2.143 & 68 & Baik \\
\hline 3 & Pelibatan karyawan & 361 & 68,8 & Baik \\
\hline 4 & Pendekatan Proses & 760 & 72,4 & Baik \\
\hline 5 & Pendekatan Sistem & 746 & 71,1 & Baik \\
\hline 6 & $\begin{array}{l}\text { Perbaikan } \\
\text { Berkesinambungan }\end{array}$ & 1.742 & 66,4 & Cukup \\
\hline 7 & Pendekatan Fakta & 747 & 71,1 & Baik \\
\hline 8 & $\begin{array}{l}\text { Hubungan Pemasok } \\
\text { saling Menguntungkan }\end{array}$ & 1.048 & 66,5 & Baik \\
\hline 9 & UNY & 11.104 & 68,2 & Baik \\
\hline
\end{tabular}


Pada ISO 9001: 2008, terdapat delapan prinsip manajemen mutu yang berintegrasi pada klausul-klausul ISO. Secara keseluruhan menurut persepsi karyawan subag pendidikan dengan didukung dengan persepsi mahasiswa dalam implementasi delapan prinsip ISO tersebut yaitu

- Fokus pada pelanggan indikator yaitu Memahami dan memenuhi kebutuhan mahasiswa dalam bidang administrasi akademik, merencanakan kegiatan dalam melayani administrasi akademik kepada mahasiswa, mencoba melakukan sesuatu yang melebihi harapan dalam melayani mahasiswa. Hasil penelitian dari prinsip fokus pada pelanggan dengan skor 4.237 atau $80,3 \%$, termasuk kategori baik, sementara persepsi mahasiswa dengan skor 3.557 atau $67,7 \%$, termasuk dalam kategori cukup. Adanya perbedaan kategori ini disebabkan menurut persepsi mahasiswa ada beberapa fakultas yaitu FT, FBS, FMIPA, FIS memperoleh total skor yang rendah dan berkategori cukup. Selain itu mahasiswa memberikan jawaban cukup sebanyak $42 \%$. Ini menjadi perhatian, bahwa pelayanan yang diberikan karyawan Subag Pendidikan dan Subag Akademik masih perlu ditingkatkan lagi.

- Kepemimpinan dengan indikator yaitu mempertimbangkan semua kebutuhan pihak terkait dalam pengambilan kebijakan, menciptakan visi dan tujuan organisasi ke depan, memberikan kebebasan untuk bertindak dengan tanggung jawab dan akuntabilitas, memberikan contoh dalam kejujuran, moral dan penciptaan budaya. Hasil penelitian dari prinsip kepemimpinan ini yaitu, dengan skor total 4.509 atau $78,3 \%$, berkategori baik sedangkan persepsi mahasiswa yaitu jumlah skornya 2.143 atau $68 \%$ serta berkategori baik.

- Pelibatan karyawan dengan indikator yaitu pelibatan Karyawan dalam pelaksanaan program kerja dan tanggung jawab kerjanya dan menciptakan lingkungan kerja yang kondusif. Hasil dari penelitian ini dengan skor 1.915 atau $79,8 \%$ yang termasuk dalam kategori baik, dan persepsi mahasiswa dengan jumlah skor 361 atau 68,8\% dan termasuk kategori baik.

- Pendekatan proses dengan indikator melakukan penekanan pada pengendalian masukan (input), proses dan keluaran output ketika melaksanakan administrasi akademik. Hasil dari penelitian ini dengan total skornya 1.136 dengan $78,9 \%$ dalam kategori baik, sedangkan persepsi mahasiswa yaitu skor total 760 atau $72,4 \%$ dengan berkategori baik.

- Pendekatan sistem pada manajemen, dengan indikator yaitu mengidentifikasi, memahami dan mengelola administrasi akademik dari proses yang saling terkait satu dengan lainnya. Hasil data dari prinsip ini dengan total skornya 1.062 atau $73,8 \%$ dan termasuk kategori baik, sementara persepsi mahasiswa yaitu skor totalnya 746 atau $71,1 \%$ dan berkategori baik.

- Pendekatan perbaikan berkesinambungan dengan inikator melakukan peningkatan pelayanan administrasi akademik kepada mahasiswa dan merevisi dan mengganti sesuatu untuk mencapai yang lebih baik. Hasil dari penelitian prinsip ini dengan skor totalnya yaitu 1.910 atau $79,6 \%$ dan berkategori baik, sedangkan persepsi mahasiswa memperoleh total skor 1.742 atau $66,4 \%$ dengan berkategori cukup. Perbedaan kategori antara persepsi karyawan dan persepsi mahasiswa ini disebabkan adanya persepsi mahasiswa di fakultas yang memperoleh skor rendah bila dibandingkan dengan Pascasarjana atau FIK dan termasuk dalam kategori cukup. Hal ini ditandai dengan jawaban yang diberikan mahasiswa yang 38\% menjawab cukup, sehingga pelaksanaan prinsip ini masih perlu ditingkatkan pelayanannya.

- Pendekatan fakta dengan indikator pengambilan keputusan berdasarkan analisis data dan informasi yang dapat dipertanggungjawabkan. Hasil dari data penelitian prinsip ini adalah dengan perolehan skor hasilnya yaitu 1.865 atau $77,7 \%$ serta berkategori baik. Sedangkan 
persepsi mahasiswa yaitu dengan total skor 747 atau $71,14 \%$, dan termasuk dalam kategori baik.

- Pemasok yang saling menguntungkan dengan indikator menciptakan hubungan dengan mahasiswa yang saling menguntungkan. Hasil dari penelitian dari prinsip ini dengan jumlah skornya 804 atau $83,75 \%$ serta berkategori baik. Sementara persepsi mahasiswa yaitu dengan total skor yaitu 1.048 atau 66,5\% dan berkategori baik.

- Implementasi delapan prinsip ISO 9001: 2008 dengan indikator semua dari pelaksanaan indikator-indikator yang terdapat dalam delapan prinsip ISO 9001: 2008 tadi. Hasil dari penelitian ini adalah di tingkat UNY dengan total skornya yaitu 17.438 atau $78,9 \%$, serta sudah berkategori baik, sedangkan persepsi mahasiswa dengan total skor 11.104 atau $68,2 \%$. juga berkategori baik.

Faktor penghambat dan solusinya dikelompokkan menjadi lima bagian yaitu :

- Adanya kendala dalam kebijakan pimpinan dan kurangnya komunikasi dengan bawahan. Solusi atau pemecahan adalah karayawan berpanduan pada peraturan-peraturan dan buku kurikulum serta pendekatan baik formal atau informal tetap ditingkatkan.

- Keterbatasan Sarana dan Prasarana. Pemecahan masalah dengan melakukan memperbaiki jaringan internet secara rutin dan penataan ruangan serta pengadaan sarana dan prasarana.

- Kurang lancarnya pengelolaan Sistem Informasi Manajemen. Solusi atau pemecahan masalah dengan pemberian informasi yang jelas dan terarah, pembuatan berbagai data base guna mendukung program SIM, serta perawatan internet dan komputer secara rutin.

- Keterbatasan dan kurangnya profesionalitas sumber daya manusia. Solusi yang ditempuh dengan mengusulkan kepada pimpinan untuk mengadakan pelatihan karyawan serta pengadaan karyawan baru.

- Keterbatasan sumber dana, pemecahan masalahnya yaitu dengan mengusulkan kepada pimpinan untuk memberikan insentif yang cukup bagi ketercapaian sasaran.

\section{Simpulan dan Saran}

\section{Simpulan}

Implementasi delapan prinsip ISO 9001: 2008 di tingkat UNY dengan total skornya yaitu 17.438 atau $78,9 \%$, serta sudah berkategori baik, sedangkan persepsi mahasiswa dengan total skor 11.104 atau $68,2 \%$. juga berkategori baik. Jika melihat dari hasil skor dan persentase dari persepsi karyawan dan persepsi mahasiswa, terjadi perbedaan sebesar $10 \%$. Hal ini terjadi dikarenakan pada persepsi mahasiswa terutama pada prinsip fokus pada pelanggan dan prinsip perbaikan berkesinambungan masih termasuk dalam kategori cukup. Sehingga pada pelaksanaan kedua prinsip tersebut masih perlu ditingkatkan pelaksanaannya.

Faktor penghambat adalah terletak pada kebijakan pimpinan fakultas, ketersediaan dana, SDM, keterbatasan sarana dan prasarana, SIM, SOP layanan administrasi. Solusi yang dilakukan adalah pererat kooordinasi dan komunikasi dengan pimpinan, perawatan rutin sarana dan prasarana, berpedoman pada buku panduan dan peraturan yang ada.

Berdasarkan pembahasan dan kesimpulan di atas, menunjukkan bahwa implementasi penyelenggaraan ISO 9001: 2008 dalam bidang mutu layanan administrasi akademik di UNY berdasarkan persepsi karyawan bagian layanan administrasi akademik telah memberikan dampak yang positif dalam peningkatan pelayanannya. Hal tersebut terlihat dari implementasi delapan prinsip ISO 9001: 2008 oleh karyawan dalam menjalankan tugasnya, sehingga memperlancar jalannya program kerja layanan administrasi akademik. Namun dalam pelaksanaannya belum berjalan optimal. Hal ini ditandai dengan data pendukung yang berasal dari mahasiswa UNY dengan hasil masih belum sesuai dengan layanan yang diha- 
rapkannya. Oleh karena itu pihak Subag Pendidikan dan Subag Akademik dapat menjadikan hasil penelitian tersebut sebagai bahan instrospeksi diri bagi karyawan dalam pemberian layanannya. Selain itu juga dapat dijadikan dasar dalam meningkatkan pelayanan yang diberikan kepada pe-langgan terutama mahasiswa. Dengan demikian diharapkan ini menjadi modal dalam menuju World Class University dan bersaing dengan universitas lainnya.

\section{Saran}

- Implementasi delapan prinsip ISO 9001: 2008 secara umum sudah terlaksana. Namun ada beberapa hal yang perlu ditingkatkan antara lain komunikasi dan koordinasi antara pimpinan dan bawahan, kualitas dan kuantitas SDM, sarana dan prasarana, Sistem Informasi Manajemen administrasi akademik, SOP layanan administrasi akademik yang lebih diperjelas keberadaanya.

- Subag Pendidikan dan jajaran pimpinan di UNY berkomitmen untuk menciptakan dan membangun budaya mutu secara terus menerus dan berkesinambungan. Subag Pendidikan dan Jajaran pimpinan di UNY sebaiknya selalu memberikan sosialisasi kepada seluruh warga UNY agar melaksanakan ISO 9001: 2008 secara totalitas.

- Kondisi ruangan, tempat tunggu, fasilitas komputer Subag Pendidikan sebaiknya diatur ulang agar mahasiswa merasa nyaman pada saat menggunakan dan atau menunggu proses layanan di Subag Pendidikan terutama di Subag Pendidikan tingkat Fakultas yaitu FBS, FE dan FT. Dalam hal ini Subag Pendidikan dapat berkoordinasi dengan pihak terkait untuk meningkatkan pelayanan terkait dengan hal tersebut.

\section{Daftar Pustaka}

Agus Syukur. (2010). 5 R, ISO 9001: 2008 dan POKAYOKE, strategi jitu manajemen mutu perusahaan. Yogyakarta: Kata Buku.
Ball, Stephen. (2007). Leadership of academics in research. Journal educationnal management administration $\mathcal{E}$ leadership. 1741-1432, Vol 35, p-449.

Goldstrein, E. Bruce. (2010). Sensation and perception (8 ed). Arizona: USA, Wads Worth Cengage Learning.

Husd, Amy R, Barcelona, Robert J and Meldrum, John T. (2008). Leisure services management. Champign USA: Human Kinetics.

Illa Sailah. (2011). Banyak perguruan tinggi di Indonesia belum melaksanakan system jaminan mutu. Diakses Error! Hyperlink reference not valid.Tanggal 10 Oktober 2011.

ISO Central, Secretariat. (2010). ISO strategic plan, 2005-2010. www.iso.org diakses pada tanggal 20 Oktober 2011.

Murdifin Haming \& Mahfud Nurnajamuddin. (2007). Manajemen produksi modern: operasi manufaktur dan jasa. Jil.ke-1. Jakarta: Bumi Aksara.

Muhammad Nur Nasution. (2003). Manajemen mutu terpadu. Jakarta: Ghalia Indonesia.

Ratminto \& Atik Septi Winarsih. (2008). Manajemen pelayanan. Yogyakarta: Pustaka Pelajar.

Vincent Gaspersz. (2003). Total quality management. Jakarta: Gramedia.

(2006). Total quality management (tgm) untuk praktisi bisnis dan industri. Jakarta: Gramedia Pustaka Utama.

Rudi Suardi. (2003). Sistem manajemen mutu ISO 9001: 2000, penerapannya untuk mencapai TQM. Jakarta: PPM.

Sallis, Edward. (2010). Total quality management in education: manajemen mutu pendidikan. (Terjemahan Ahmad Ali Riyadi dan Fahrurozi). London: Kogan Page. (Buku asli diterbitkan tahun 1993). 
Schuk, Dale H. (2009) Learning Theories An Educational Perspective, New Jersey: Pearson Education.

STMicroelectronics. (2010). STMicroelectronics reaffirms and demonstrates commitment to quality; achieves ISO 9001:2008 and ISO/TS 16949: 2009 certification renewals. Diambil pada tanggal 25-11-2010.proquest.com/ doc-view $/ 200266921$ ?accountid=38628.

Sofyan Riyanto. (2010). Peran sertifikasi sistem manajemen kualitas ISO 9001: 2008 terhadap kepuasan pengguna di Perpustakaan Universitas Sanata Dharma Tahun 2010, Yogyakarta: UGM (Tesis).
Stoner, James A.F and Wankel, Charles. (1987). Management, 3 rd Ed. New Delhi; Prentice Hall of India.

Sudarwan Danim. (2007). Visi baru manajemen sekolah dari unit birokrasi ke lembaga akademik. Jakarta: PT. Bumi Aksara.

Sugiyono. (2011). Metode penelitian kuantitatif, kualitatif, dan kombinasi (mixed methods). Bandung: Alfabeta.

Syafaruddin. (2002). Manajemen mutu terpadu dalam pendidikan, konsep, strategi, dan aplikasi. Jakarta: Grasindo.

Theodorus Hani Handoko. (2003) Manajemen. Yogyakarta: BPFE. 